\title{
WATER USE EFFICIENCY AND SPAD INDEX OF FRUIT TREES GROWN UNDER DIFFERENT WATER CONDITIONS
}

\author{
Department of Agronomy, West Pomeranian University of Technology, Szczecin, Poland
}

\begin{abstract}
The experiment was conducted in 2015 and 2016 in the Agricultural Experimental Station in Lipnik $\left(53^{\circ} 20^{\prime} 35^{\prime \prime} \mathrm{N} 14^{\circ} 58^{\prime} 10^{\prime \prime} \mathrm{E}\right)$, Poland. The main goal of the study was to assess the characteristic features associated with water use efficiency and index of leaf greening of fruit trees. The experiment was designed by the randomized block method in 7 replications (one tree - one replicate) for cherry cv. 'Łutówka', 5 replications for sweet cherry cv. 'Vanda', 7 replications for apple cv. 'Rubinola' and 4 replication for plum cv. 'Amers'. The experimental factor was under-crown watering: 0 - control objects with no irrigation, $\mathrm{W}$ - irrigated objects, at the level of moisture $-0.01 \mathrm{MPa}$ of the water potential. Irrigated cherry and sweet cherry trees were characterized by significantly lower assimilation and transpiration intensity as well as stomatal conductance. In apple and plum cultivation, irrigation remarkably enhanced the assimilation and transpiration intensity. All tested fruit tree species grown on irrigated objects were distinguished by higher value of water use efficiency (WUE) and momentary water use efficiency (WUEI). Index of leaf greening was significantly lower for irrigated trees.
\end{abstract}

Key words: fruit trees, index of leaf greening (SPAD), momentary water use efficiency, photosynthetic activity, water use efficiency.

\section{INTRODUCTION}

Physiological processes occurring within plants, such as transpiration, photosynthesis, cell and tissue growth as well as cell firmness, are directly associated with water availability (Sarker et al. 2005). When plants are subject to a strong competence in an environment, physiological traits of growth and development are usually altered leading to differences in resources utilization, namely in the case of water use, and it has a direct impact on $\mathrm{CO}_{2}$ availability in leaves and leaf temperature, thus the photosynthetic efficiency (Procópio 2004).

Water use efficiency (WUE) becomes a key issue in agriculture, particularly on areas characterized by negative water balance. Water deficiency, drought, is one of the main restraints that reduce production and quality of worldwide crops (Boutraa et al. 2010). Taking into account the fact that prediction of climatic changes include temperature increase along with drought, the improvement in water use efficiency (WUE) of crops becomes the main objective in agriculture and food safety (Medrano et al. 2015).

The water issue is also important for stone fruits trees cultivation, because of the fact that large proportion of crops is localized on areas with negative water balance and regular water

Corresponding author - Adres do korespondencji: Anna Jaroszewska, Department of Agronomy, West Pomeranian University of Technology, Szczecin, Papieża Pawła VI 3, 71-459 Szczecin, Poland, e-mail: anna.jaroszewska@zut.edu.pl 
applications are necessary to their proper growth and development. Dependencies between plant's water supply and their photosynthetic activity are confirmed by previous research (Jezdinský and Pokluda 2016).

Chlorophyll content is a key factor affecting the photosynthetic activity of plants, because photosynthetic pigments make possible to absorb light energy by plants (Taiz and Zeiger 2006). Moreover, evaluation of pigments in a plant may be an important factor $f$ their aging, and due to a strict association with environmental stress, it may be a good indicator of a stress within plants. The chlorophyll-meter (SPAD-502) is a simple, portable diagnostic tool that measures the greenness or relative content of leaves (Netto et al. 2005).

Knowledge on the influence of irrigation on photosynthetic activity and water use efficiency in fruit orchards is still insufficient. Previous studies on that issue relate mainly to berry plant species (Souza et al. 2005; Klamkowski and Treder 2010; El-Mageed and Semida 2015).

Therefore, the aim of present work was to evaluate the characteristic features associated with water use efficiency and index of leaf greening at four fruit trees species grown under different water conditions in Central Europe (north-western Poland).

\section{MATERIAL AND METHODS}

The experiment was conducted in 2015 and 2016 in the Agricultural Experimental Station

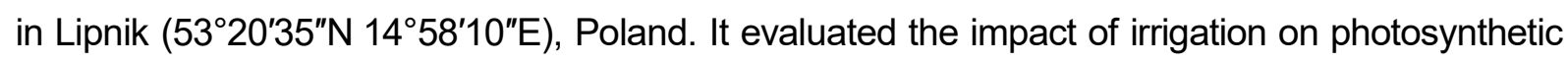
activity and water use efficiency in four species of fruit trees: cherry cv. 'Łutówka', sweet cherry cv. 'Vanda', apple cv. 'Rubinola' and plum cv. 'Amers'. The soil, on which the experiment was conducted, belongs to the typical rusty soils group (Polish Soils Classification 2011) and is classified as Haplic Cambisol (IUSS Working Group WRB 2015). In the Ap level (arable-humus horizon), it has a granulometric composition of clay sand with a slightly acidic $\mathrm{pH}$. The content analysis of the soil minerals showed high levels of phosphorus and moderate levels of magnesium and potassium. The experiment was designed by the randomized block method in 7 replications (one tree - one replicate) for cherry cv. 'Łutówka', 5 replications for cherry cv. 'Vanda', 7 replications for apple cv. 'Rubinola' and 4 replication for plum cv. 'Amers'. Among the trees, there was the lawn, but in the rows, the selective herbicide fallow was kept. The trees were planted in $4 \times 2 \mathrm{~m}$ spacing (cherry cv. 'Łutówka'), $3.5 \times 3 \mathrm{~m}$ (sweet cherry cv. 'Vanda'), $3.5 \times 2$ m (apple cv. 'Rubinola') and $4.5 \times 4$ m (plum cv. 'Amers'). The research started on trees in 16th (cherry cv. 'Łutówka'), 13th (sweet cherry cv. 'Vanda'), 14th (apple cv. 'Rubinola') and 17th (plum cv. 'Amers') year after planting. The experimental factor was under-crown watering: 0 - control objects with no irrigation, $\mathrm{W}$ - irrigated objects, at the level of moisture $-0.01 \mathrm{MPa}$ of the water potential. Hadar micro-sprinklers were used for watering, sprinkler range $r=1 \mathrm{~m}$ and efficiency of $2.5 \mathrm{I} \cdot \mathrm{h}^{-1}$; one sprinkler per each tree. Determination of the doses and times of irrigation was performed using tension-meters buried $20 \mathrm{~cm}$ below the soil surface. The amounts of water applied to the trees is shown in Table 1. 
Table 1. Water dose applied in years of experiment

\begin{tabular}{cccccc}
\hline & Years & $\begin{array}{c}\text { Cherry } \\
\text { 'Łutówka' }\end{array}$ & $\begin{array}{c}\text { Cherry } \\
\text { 'Vanda' }\end{array}$ & $\begin{array}{c}\text { Apple } \\
\text { 'Rubinola' }\end{array}$ & $\begin{array}{c}\text { Plum } \\
\text { Amers' }\end{array}$ \\
\hline 2015 & $\mathrm{~m}^{3} \cdot$ tree $^{-1}$ & 0.14 & 0.18 & 0.20 & 0.24 \\
& {$[\mathrm{~mm}]$} & 117 & 90 & 250 & 171 \\
2016 & $\mathrm{~m}^{3} \cdot \mathrm{tree}^{-1}$ & 0.07 & 0.09 & 0.10 & 0.12 \\
& {$[\mathrm{~mm}]$} & 58 & 45 & 125 & 86 \\
\hline
\end{tabular}

Meteorological conditions during the years of study are presented in Table 2. Referring to many-year period (1961-2004 y), years when experiment was conducted were warmer and apparently dryer. The air temperature was higher by $0.7^{\circ} \mathrm{C}$ and $1.1^{\circ} \mathrm{C}$, respectively. Precipitation sum in subsequent years was respectively lower by 78.1 and $63.4 \mathrm{~mm}$.

Table 2. Sum of rainfall and mean air temperature in 2015-2016 years comparison to long-term average 1961-2004

\begin{tabular}{lcccrrr}
\hline \multirow{2}{*}{ Month } & \multicolumn{2}{c}{ Long-term averages 1961-2004 } & \multicolumn{2}{c}{ Precipitation [mm] } & \multicolumn{2}{c}{ Air temperature $\left[{ }^{\circ} \mathrm{C}\right]$} \\
\cline { 2 - 7 } & $\begin{array}{c}\text { precipitation } \\
{[\mathrm{mm}]}\end{array}$ & $\begin{array}{c}\text { temperature } \\
{\left[{ }^{\circ} \mathrm{C}\right]}\end{array}$ & 2015 & 2016 & 2015 & 2016 \\
\hline IV & 34.9 & 8.9 & 15.4 & 19.7 & 8.3 & 8.1 \\
V & 48.6 & 13.2 & 44.3 & 41.2 & 12.3 & 15.6 \\
VI & 61.7 & 16.2 & 46.9 & 79.9 & 16.5 & 17.9 \\
VII & 70.9 & 18.1 & 63.9 & 70.8 & 19.4 & 18.5 \\
VIII & 54.1 & 18.1 & 19.6 & 33.5 & 21.6 & 17.4 \\
IX & 51.6 & 13.6 & 53.6 & 13.3 & 14.5 & 16.6 \\
IV-IX & 321.8 & 14.7 & 243.7 & 258.4 & 15.4 & 15.8 \\
\hline
\end{tabular}

The measurements of the leaf photosynthetic activity in each year were taken using a LCA-4 analyzer (ADC Bioscentific LTD, Hoddeson, Great Britain), in the period of fruit setting. Following measurements were conducted: NET photosynthesis intensity $\left(P_{n}\right)$, leaf transpiration index $(E)$, internal $\mathrm{CO}_{2}$ concentration $\left(\mathrm{C}_{\mathrm{i}}\right)$ and stomatal conductivity $\left(\mathrm{g}_{\mathrm{c}}\right)$. The photosynthesis water use efficiency (WUE) was determined on basis of the ratio of the photosynthesis index to the transpiration $\left(\mathrm{P}_{\mathrm{n}} / \mathrm{E}\right)$. The momentary water use efficiency (WUEI) was assessed on basis of the ratio of the photosynthesis intensity to stomatal conductivity $\left(P_{n} / g_{c}\right)$.

The measurements of the leaf greening in each year were taken using chlorophyll meter SDAD 520 (produced by Minolta) in the period of fruit setting.

The measurements (photosynthetic activity and index of leaf greening) was conducted on fully developed leaves without any signs of ageing or mechanical damage. The leaves chosen for the measurements were well developed, taken from the middle part of one-year-old shoots on the outer part of tree crown, in the middle of its height.

All data were analyzed using the Statistica Program, version 12 (Statsoft, Poland). In order to determine the significance of the differences in photosynthetic activity, water use efficiency (WUE), momentary water use efficiency (WUEI) and index of leaf greening of the analyzed plants, the one-way analysis of variance (ANOVA) was conducted. The significance of differences between means was compared by Tukey's range test. Statistical significance was considered at $p \leq 0.05$. The correlations between parameters were determined using the Pearson's simple correlation test. Results were presented as the mean for two years of experiment \pm SD (standard deviation). 


\section{RESULT AND DISCUSSION}

Influence of irrigation on photosynthetic activity of four fruit trees species is presented in Table 3. In the experiment, the water factor significantly differentiated values of tested features in leaves of all analyzed tree species.

Table 3. Photosynthetic activity (mean \pm standard deviation)

\begin{tabular}{|c|c|c|c|c|c|}
\hline Irrigation & $P_{n}$ & $\mathrm{E}$ & $\mathrm{C}_{\mathrm{i}}$ & $g_{c}$ & $T_{\text {leaf }}$ \\
\hline \multicolumn{6}{|c|}{ Cherry 'Łutówka' } \\
\hline $\mathrm{O}$ & $13.6^{a} \pm 0.73$ & $3.74^{\mathrm{a}} \pm 0.27$ & $294.2^{\mathrm{a}} \pm 30.0$ & $0.30^{\mathrm{a}} \pm 0.03$ & 25.0 \\
\hline W & \multicolumn{5}{|c|}{ Sweet cherry 'Vanda' } \\
\hline $\mathrm{O}$ & $11.8^{a} \pm 0.99$ & $2.55^{\mathrm{a}} \pm 0.42$ & $173.3^{b} \pm 9.09$ & $0.27^{a} \pm 0.03$ & 24.0 \\
\hline W & \multicolumn{2}{|c|}{ Apple 'Rubinola' } & $a^{\prime} 255.7^{a} \pm 13.8$ & & 24.0 \\
\hline $\mathrm{O}$ & $6.55^{b} \pm 0.59$ & $2.57^{a} \pm 0.26$ & $314.3^{a} \pm 11.2$ & $0.18^{a} \pm 0.00$ & 25.0 \\
\hline \multicolumn{6}{|c|}{ Plum 'Amers' } \\
\hline $\begin{array}{l}\mathrm{O} \\
\mathrm{W}\end{array}$ & $\begin{array}{l}9.05^{b} \pm 1.02 \\
10.3^{a} \pm 0.49\end{array}$ & $\begin{array}{l}2.38^{a} \pm 0.13 \\
2.42^{a} \pm 0.15\end{array}$ & $\begin{array}{l}290.9^{\mathrm{a}} \pm 2.42 \\
288.2^{\mathrm{a}} \pm 9.08\end{array}$ & $\begin{array}{l}0.17^{a} \pm 0.01 \\
0.18^{a} \pm 0.01\end{array}$ & $\begin{array}{l}25.0 \\
25.0\end{array}$ \\
\hline
\end{tabular}

$\mathrm{O}$ - control (without irrigation), $\mathrm{W}$ - irrigation, $\mathrm{P}_{\mathrm{n}}$ - the intensity of assimilation [umol $\mathrm{CO}_{2} \cdot \mathrm{m}^{-2} \cdot \mathrm{s}^{-1}$ ], $\mathrm{E}-$ intensity of transpiration [mmol $\mathrm{H}_{2} \mathrm{O} \cdot \mathrm{m}^{-2} \cdot \mathrm{s}^{-1}$ ], $\mathrm{g}_{\mathrm{c}}$ - stomatal conductance [mmol $\mathrm{H}_{2} \mathrm{O} \cdot \mathrm{m}^{-2} \cdot \mathrm{s}^{-1}$ ], $\mathrm{C}_{\mathrm{i}}$ - the concentration of $\mathrm{CO}_{2}$ into the distance intercellular [umolCO $2 \cdot \mathrm{mol}^{-1}$ air], Tleaf - temperature $\left[{ }^{\circ} \mathrm{C}\right]$. Means with the same letters do not different significantly.

In opinion of Wibbe and Blanke (1997), the decrease in photosynthetic activity can result both from the lack of water and its excess. For leaves of irrigated cherry and sweet cherry, assimilation intensity $\left(P_{n}\right)$ was significantly lower by $29 \%$ and $17 \%$, respectively, as compared to non-irrigated ones. According to Mafakheri et al. (2010), better water supply resulted in significantly higher net-photosynthesis. The discussed experiment revealed that apple and plum trees were characterized by different reaction than cherry and sweet cherry. Significantly higher assimilation intensity was found in irrigated leaves of both species than in non-irrigated ones, respectively by $20 \%$ and $14 \%$. The drought stress affected the significantly higher transpiration intensity $(E)$ in leaves of non-irrigated cherry and sweet cherry (by $29 \%$ and $31 \%$ ), which was confirmed by earlier study of Jaroszewska (2015). Higher assimilation intensity and higher transpiration intensity may be related to the individual reaction of the plant to stress and its intensity. The reaction of a plant to a lack of water depends both on its individual resistance to drought as well as on other environmental conditions (Kacperska 1998). Cherry and sweet cherry go through a longer process of adapting to the changing rainfall conditions caused by, among others, irrigation. Despite of the fact that no significant influence of the water factor on transpiration intensity in apple and plum trees was observed, a tendency to the increase in transpiration in both irrigates species, was recorded. Previous experiments (Rouphael et al. 2008) have shown that along with the decrease in stomatal conductance $\left(g_{c}\right)$, assimilation $(A)$ is also lowered, which was in part confirmed by own studies (Table 3). According to Chaves and Oliviera (2004), under conditions of strong drought stress, stomatal conductance only affects the assimilation intensity. In own study, stomatal conductance was significantly higher in leaves of nonirrigated trees as compared to those that were irrigated (for cherry - even twice as high), which does not correlate with research by Mafakheri et al. (2010), who found that stomatal 
conductance decreased as one of the first responses of plants to drought is stomatal closure, estricting gas exchange between the atmosphere and the inside of the leaf. The concentration of $\mathrm{CO}_{2}$ into the distance intercellular was remarkably higher in leaves of non-irrigated sweet cherry (by $25 \%$ ), apple (by $23 \%$ ) and plum (by $1 \%$ ), which according to Mafakheri et al. (2010) results from the drought.

Water use efficiency (WUE) very well describes the water balance at plants during their vegetation. High WUE is largely a function of reduced water use rather then a net improvement in plant production or biochemistry of assimilation (Blum 2005). In present experiment, rather irrigated than non-irrigated trees were characterized by higher water use efficiency index (Table 4); in the case of cherry - by $65 \%$, plum - by $12 \%$, while apple - over 2-fold. No statistically significant difference in water use was found for irrigated and nonirrigated sweet cherry trees. Transpiration intensity is associated with the use efficiency of water available for plants during vegetation (Olszewska and Grzegorczyk 2013). Calculated coefficient of photosynthetic water use revealed that cherry and sweet cherry trees, that transpired significantly more water, were characterized by its low use.

Table 4. Water use efficiency (WUE) and momentary water use efficiency (WUEI) (mean \pm standard deviation)

\begin{tabular}{|c|c|c|c|c|c|}
\hline & & $\begin{array}{l}\text { Cherry } \\
\text { 'Łutówka' }\end{array}$ & $\begin{array}{c}\text { Sweet cherry } \\
\text { 'Vanda' }\end{array}$ & $\begin{array}{c}\text { Apple } \\
\text { 'Rubinola' }\end{array}$ & $\begin{array}{l}\text { Plum } \\
\text { 'Amers' }\end{array}$ \\
\hline \multirow[t]{2}{*}{ WUE } & $\mathrm{O}$ & $3.65^{b} \pm 0.29$ & $4.63^{a} \pm 0.98$ & $2.55^{b} \pm 0.32$ & $3.80^{b} \pm 0.34$ \\
\hline & W & $6.00^{a} \pm 0.95$ & $5.02^{a} \pm 0.53$ & $5.37^{a} \pm 0.46$ & $4.25^{a} \pm 0.23$ \\
\hline \multirow[t]{2}{*}{ WUEl } & $\mathrm{O}$ & $45.2^{b} \pm 4.77$ & $43.7^{b} \pm 6.83$ & $36.4^{b} \pm 2.79$ & $53.2^{b} \pm 6.22$ \\
\hline & W & $74.6^{a} \pm 7.24$ & $70.0^{a} \pm 6.36$ & $96.0^{a} \pm 6.49$ & $57.2^{\mathrm{a}} \pm 2.87$ \\
\hline
\end{tabular}

WUE - water use efficiency [ $\mu \mathrm{mol} \mathrm{CO}_{2} \cdot \mathrm{m}^{-2} \cdot \mathrm{s}^{-1} \mathrm{~m} \mathrm{~mol} \mathrm{H}_{2} \mathrm{O} \cdot \mathrm{m}^{-2} \cdot \mathrm{s}^{-1}$ ], WUEI - momentary water use efficiency [ $\mu \mathrm{mol} \mathrm{CO}_{2} \cdot \mathrm{m}^{-2} \cdot \mathrm{s}^{-1} \mathrm{~m} \mathrm{~mol} \mathrm{H}_{2} \mathrm{O} \cdot \mathrm{m}^{-2} \cdot \mathrm{s}^{-1}$ ]. Means with the same letters do not different significantly. Other explanations see Table 3 .

Momentary water use efficiency (WUEI) determined by genetic traits of a plant significantly depended on the irrigation applied (Table 4). All tested tree species grown on irrigated object - as compared to non-irrigated ones - were distinguished by remarkably higher WUEl values. The highest levels of this trait were recorded for apple (aver twice as high), cherry (by 65\%) and sweet cherry (by 60\%). The lowest difference in momentary water use efficiency between irrigated and non-irrigated objects, was found for plum, for which this trait was higher by $7 \%$ for irrigated trees.

Up-to-date studies (Xu and Leskovar 2014) upon the influence of the water factor on index of leaf greening, that is correlated with the chlorophyll content (Liu et al. 2015), indicate its remarkable effect on this trait. According to Mafakheri et al. (2010) and Kirnak et al. (2001), drought stress significantly decreases the chlorophyll content of crops. In own study, significantly lower value of greening index was recorded in irrigated leaves of all analyzed tree species (Table 5): by $10 \%$ in cherry, by $4 \%$ in sweet cherry, by $8 \%$ in apple, and by $11 \%$ in plum. Other authors (Podsiadło and Jaroszewska 2013) have also reported that smaller values of index of leaf greening were shown by leaves of irrigated plants. The photosynthesis activity does not depend on the chlorophyll content, but on its photosynthetic activity. Only part of chlorophyll takes part in the photosynthesis process, and stress-exposed plants contained much more of this chemical. 
Table 5. Mean SPAD readings in the period of fruit setting (mean \pm standard deviation)

\begin{tabular}{ccccc}
\hline & $\begin{array}{c}\text { Cherry } \\
\text { 'Lutówka' }\end{array}$ & $\begin{array}{c}\text { Sweet cherry } \\
\text { 'Vanda' }\end{array}$ & $\begin{array}{c}\text { Apple } \\
\text { 'Rubinola' }\end{array}$ & $\begin{array}{c}\text { Plum } \\
\text { 'Amers' }\end{array}$ \\
\hline $\mathrm{O}$ & $42.9^{\mathrm{a}} \pm 1.62$ & $39.0^{\mathrm{a}} \pm 1.76$ & $45.3^{\mathrm{a}} \pm 1.33$ & $40.9^{\mathrm{a}} \pm 1.73$ \\
$\mathrm{~W}$ & $38.8^{\mathrm{b}} \pm 1.19$ & $37.3^{\mathrm{b}} \pm 0.88$ & $41.6^{\mathrm{b}} \pm 1.37$ & $36.4^{\mathrm{b}} \pm 1.61$ \\
\hline
\end{tabular}

Explanations see Table 3.

According to Flexas and Medrano (2002), closing the stomatal conductance and resulting $\mathrm{CO}_{2}$ deficit in chloroplasts can be the main reason for photosynthesis drop during the gentle and moderate stress. Own study has shown that lower photosynthetic intensity was recorded in irrigated leaves of cherry and sweet cherry trees characterized by significantly lower stomatal conductance and index of leaf greening.

It was found in present experiment and previous reports (Silva et al. 2013) that photosynthetic activity of fruit trees leaves was directly connected to the water use efficiency (WUE) and momentary water use efficiency (WUEI) (Table 6). There were highly significant negative correlations between photosynthetic activity and WUE and WUEI in cherry cultivation. Highly significant negative correlations were also recorded between transpiration intensity and stomatal conductance as well as WUE and WUEI in sweet cherry cultivation, and between concentration of $\mathrm{CO}_{2}$, stomatal conductance as well as WUE and WUEI in apple cultivation. Highly significant positive correlations were found for assimilation and WUE as well as WUEI for apple and plum crops.

Table 6. Simple correlation coefficients ( $r$ ) between photosynthetic activity, and WUE and WUEI

\begin{tabular}{|c|c|c|c|}
\hline Correlation (r) & & WUE & WUEI \\
\hline Cherry & $P_{n}$ & -0.70 & -0.83 \\
\hline \multirow[t]{3}{*}{ 'Łutówka' } & $E$ & -0.92 & -0.93 \\
\hline & $\mathrm{C}_{\mathrm{i}}$ & -0.65 & -0.79 \\
\hline & $g_{c}$ & -0.82 & -0.97 \\
\hline Sweet cherry & $P_{n}$ & 0.37 & -0.51 \\
\hline \multirow[t]{3}{*}{ 'Vanda' } & $E$ & -0.72 & -0.60 \\
\hline & $\mathrm{C}_{\mathrm{i}}$ & 010 & 0.84 \\
\hline & $g_{c}$ & -0.95 & -0.95 \\
\hline Apple & $P_{n}$ & 0.98 & 0.99 \\
\hline \multirow[t]{3}{*}{ 'Rubinola' } & $E$ & 0.10 & 0.25 \\
\hline & $\mathrm{Ci}_{\mathrm{i}}$ & -0.86 & -0.88 \\
\hline & $g_{c}$ & -0.89 & -0.94 \\
\hline Plum & $P_{n}$ & 0.82 & 0.88 \\
\hline \multirow{3}{*}{ 'Amers' } & $E$ & -0.10 & 0.25 \\
\hline & $\mathrm{C}_{\mathrm{i}}$ & -0.26 & -0.13 \\
\hline & $g_{c}$ & -0.10 & -0.13 \\
\hline
\end{tabular}

Figures in bold significant. Explanations see Table 4.

\section{CONCLUSIONS}

Knowledge of fruit trees reactions towards the water factor seems to be an important aspect in modern horticulture, namely in a context of considerable water requirements of horticultural species and adverse climatic changes nowadays. Knowledge upon the water use by various fruit trees species could help in developing still lacking cultivating criteria based, among others, physiological parameters characteristic for a given species or cultivar. On the basis of up-to-date research, it was found that: 
1. Significantly lower assimilation and transpiration intensity as well as stomatal conductance characterizes irrigated cherry and sweet cherry trees. Applied irrigation enhanced assimilation and transpiration intensity in apple and plum cultivation.

2. Higher water use efficiency (WUE) and momentary water use efficiency (WUEI) indices were recorded for irrigated trees of all tested species.

3. Irrigated trees of studied species were characterized by significantly lower value of leaf greening index.

4. Photosynthetic activity correlated both with water use efficiency (WUE) and momentary water use efficiency (WUEI).

\section{REFERENCES}

Blum A. 2005. Drought resistance, water-use efficiency, and yield potential-are they compatible, dissonant, or mutually exclusive? Aust. J. Agric. Res. 56, 1159-1168.

Boutraa T., Akhkha A., Al-Shoaibi A.A., Alhejeli, A.M. 2010. Effect of water stress on growth and water use efficiency (WUE) of some wheat cultivars (Triticum durum) grown in Saudi Arabia. JTUSCI 3, 39-48.

Chaves M.M., Oliviera M.M. 2004. Mechanisms underlying plant resilience to water deficits: prospects for water-saving agriculture. J. Exp. Bot. 55(407), 2365-2384.

El-Mageed T.A.A., Semida M. 2015. Effect of deficit irrigation and growing seasons on plant water status, fruit yield and water use efficiency of squash under saline soil. Sci. Hort. 186, 89-100.

Flexas J., Medrano H. 2002. Drought-inhibition of photosynthesis in C-3 plants: Stomatal and nonstomatal limitation revisited. Ann. Bot. 89, 183-1890.

IUSS Working Group WRB. 2015. World reference base for soil resources. World Soil Resources Reports. Rome, FAO, 106.

Jaroszewska A. 2015. The effect of irrigation and mineral fertilization on the photosynthetic activity and water use in respect of cherry cv. 'Kelleris 16' yielding. Acta Sci. Pol., Hortorum Cultus 14, 109-120.

Jezdinský A., Pokluda R. 2016. Photosynthetic activity as an indicator of drought stress in vegetables. Acta Hort. 1112, 39-44.

Kacperska A. 1998. Reakcje roślin na czynniki stresowe, w: Podstawy fizjologii roślin. Ed. J. Kopcewicz. Warszawa, PWN, 583-588. [in Polish]

Kirnak H., Kaya C., Tas I., Higgs D. 2001. The influence of water deficit on vegetative growth, physiology, fruit yield and quality in eggplants. Bulg. J. Plant Physiol. 27, 34-46.

Klamkowski K., Treder W. 2010. Zużycie wody przez rośliny truskawek w uprawie pod osłonami [Estimation of water consumption by strawberry plants cultivated under greenhouse conditions]. Zesz. Nauk. Inst. Sad. Kwiac. 18, 63-70. [in Polish]

Liu Z., Hu H., Yu H., Yang X., Yang H., Ruan C., Wang Y., Tang J. 2015. Relationship between leaf physiologic traits and canopy color indices during the leaf expansion period in an oak forest. Ecosphere 6, 259.

Mafakheri A.B., Siosemardeh P.C., Bahramnejad Y., Struik T., Sohrabi S. 2010. Effect of drought stress on yield, proline and chlorophyll contents in three chickpea cultivars. Aust. J. Crop. Sci. 4, 580-585.

Medrano H., Tomás M., Martorell S., Flexas J., Hernández E., Rosselló J., Pou A., Escalona J.M., Bota J. 2015. From leaf to whole-plant water use efficiency (WUE) in complex canopies: Limitations of leaf WUE as a selection target. The Crop. J. 3, 220-228.

Netto A.T., Campostrini E., Gonc J., De Oliveira A., Bressan-Smith R.E. 2005. Photosynthetic pigments, nitrogen, chlorophylla fluorescence and spad-502 readingsin coffee leaves. Sci. Hort. 104, 199-209. 
Olszewska M., Grzegorczyk S. 2013. Oddziaływanie stresu wodnego na wybrane gatunki traw uprawianych na glebie organicznej [The effect of water stress on selected grass species grown in organic soils]. Fragm. Agron. 30, 140-147. [in Polish]

Podsiadło C., Jaroszewska A. 2013. Wpływ nawadniania i nawożenia azotem i potasem na aktywność fotosyntetyczną wiśni [Effect of irrigation and fertilization of nitrogen and potassium on photosynthetic activity of cherry]. Infr. Ecol. Rural Areas 2, 93-101. [in Polish]

Polish Soil Classification. 2011. Soil Sci. Ann. 62, 1-193.

Procópio S.O. 2004. Permanent wilting point of soybean, bean and weeds. Planta Daninha 22, $35-41$.

Rouphael Y., Cardarelli M., Colla G. 2008. Yield, mineral composition, water relations, and water use efficiency of grafted mini-watermelon plants under deficit irrigation. Hort. Sci. 43,730-736.

Sarker B.C., Hara M., Uemura M. 2005. Proline synthesis, physiological responses and biomass, yield of eggplants during and after repetitive soil moisture stress. Sci. Hort. 103, 387-402.

Silva M., Jifon J.L., Santos C.M., Jadoski C., Gonçalves da Silva G.A. 2013. Photosynthetic capacity and water use efficiency in sugarcane genotypes subject to water deficit during early growth phase. Braz. Arch. Biol. Technol. 56, 735-48.

Souza C.R., Maroco J.P., Santos T.P., Rodrigues M.L., Lopes C.M., Pereira J.S., Chaves M.M. 2005. Impact of deficit irrigation on water use efficiency and carbon isotope composition (d13C) of field-grown grapevines under Mediterranean climate. J. Exp. Bot. 56, 2163-2172.

Taiz L., Zeiger E. 2006. Plant physiology. Massachusetts, USA, Sinauer Associates Inc., Publishers.

Wibbe M.L., Blanke M.M. 1997. Effect of fruiting and draught or flooding on carbon balance of apple trees. Photosynthetica. 33, 269-275.

Xu C., Leskovar D.I. 2014. Growth, physiology and yield responses of cabbage to deficit irrigation. Hort. Sci. 41, 138-146.

\title{
WSPÓŁCZYNNIK WYKORZYSTANIA WODY I INDEKS ZAZIELENIENIA DRZEW OWOCOWYCH UPRAWIANYCH W ZRÓŻNICOWANYCH WARUNKACH WODNYCH
}

\begin{abstract}
Streszczenie. Doświadczenie prowadzono w latach 2015 i 2016 w Rolniczej Stacji Doświad-

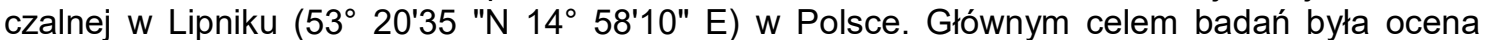
charakterystycznych cech związanych z efektywnością zużycia wody i indeksem zazielenienia liści drzew owocowych. Eksperyment został założony metodą losowanych bloków w 7 powtórzeniach (jedno drzewo - jedna replikacja, powtórzenie) dla wiśni odm. 'Kutówka', w 5 powtórzeniach dla czereśni odm. 'Vanda', w 7 powtórzeniach dla jabłoni odm. 'Rubinola' i w 4 powtórzeniach dla śliwy odm. 'Amers'. Czynnikiem doświadczalnym było nawadnianie podkoronowe: 0 - obiekty kontrolne, bez nawadniania, $\mathrm{W}$ - obiekty nawadniane, przy poziomie uwilgotnienia -0,01 MPa potencjału wodnego. Nawadniane wiśnie i czereśnie charakteryzowały się znacznie niższą intensywnością asymilacji i transpiracji oraz przewodnictwem szparkowym. W uprawie jabłek i śliwek nawadnianie znacznie zwiększyło intensywność asymilacji i transpiracji. Wszystkie badane gatunki drzew owocowych uprawiane na obiektach nawadnianych, odznaczały się wyższą efektywności zużycia wody (WUE) i chwilową efektywnością zużycia wody (WUEI). Wskaźnik zazielenienia liści był znacznie niższy dla drzew nawadnianych.
\end{abstract}

Słowa kluczowe: drzewa owocowe, indeks zazielenienia liści (SPAD), chwilowy współczynnik wykorzystania wody, aktywność fotosyntetyczna, współczynnik wykorzystania wody. 